\title{
ЗООГЕОГРАФИЧЕСКАЯ ХАРАКТЕРИСТИКА МОРСКИХ РЫБ, ОБИТАЮЩИХ ВБЛИЗИ П-ОВА КАМЧАТКА, НА ОСНОВАНИИ РАСПРЕДЕЛЕНИЯ РАННИХ СТАДИЙ РАЗВИТИЯ
}

\author{
Григорьев С. С. ${ }^{1}$, Седова Н. . $^{2}$ \\ ${ }^{1}$ КФ ФГБУН Тихоокеанского института географии ДВО РАН, г. Петропавловск-Камчатский \\ ${ }^{2}$ Камчатский государственный технический университет, г. Петропавловск-Камчатский \\ E-mail:sgri@inbox.ru, sedova67@bk.ru
}

\begin{abstract}
Рассматривается соответствие репродуктивных ареалов рыб, обитающих в прикамчатских водах и в чукотских водах западной части Берингова моря, современным представлениям об их зоогеографических характеристиках и типах ареалов распространения. Для уточнения зоогеографической оценки видов рыб рассматриваются районы нереста, различающиеся по зоогеографическим характеристикам. Отмечается, что большинство видов морских рыб с известными ранними стадиями развития, обитающих вблизи Камчатки, имеют северо-тихоокеанское распространение (75.3\%). Виды северо-западно-тихоокеанского ареала распространения составляют $17.1 \%$ от общего количества рассматриваемых видов. Небольшую долю (менее 7.6\%) составляют виды атланто-тихоокеанского ареала распространения. По зоогеографическим группировкам преобладают умеренно-бореальные (43.8\%) и северно-бореальные $(30.4 \%)$ виды. Беднее по числу видов арктическо-бореальные (около $18 \%)$ и арктические $(2.9 \%)$ рыбы. Как исключение, встречаются южно-бореальные $(3.9 \%)$ и субтропическо-бореальные (около 1\%) виды.
\end{abstract}

Ключевые слова: ихтиофауна, ихтиопланктон, зоогеографические характеристики, зоогеографические группировки, фаунистическая общность.

DOI: $10.34078 / 1814-0998-2020-3-94-108$

Данные, полученные в результате изучения зоогеографии, дают представление о распространении различных видов рыб и помогают выявить факторы, которые способствуют или препятствуют распространению видов, приводят к изменению ареала, к увеличению или сокращению численности. На основании географического распределения животных, в том числе и рыб, выделены отдельные зоогеографические области, которые, в свою очередь, разделяются на подобласти и более мелкие районы. Распространению морских рыб способствуют климатические и океанографические факторы. Общепризнано, что распространение родов и видов морских рыб определяется условиями среды, прежде всего температурой, соленостью, глубинами и др. (Шмидт, 1950; Никольский, 1974; Борец, 1997).

Фауна умеренных вод северной части Тихого океана изучается морскими биологами на протяжении более чем 100 лет. История этих исследований подробно изложена в работах К. В. Беклемишева с соавторами (1977), О. Г. Кусакина (1979), А. И. Кафанова (1991) и В. В. Петряше-

(C) Григорьев С. С., Седова Н. А., 2020 ва (2005). Исследования, выполненные на основе анализа распределения разных таксонов бентосных, планктонных или нектонных гидробионтов, позволили предложить многочисленные схемы районирования. Наиболее важной схемой можно считать выделение широтно-фаунистическозонального комплекса в виде трех подобластей: двух низкобореальных у противоположных берегов океана и одной, единой, высокобореальной (Голиков, Кусакин, 1962; Кусакин, 1979; Петряшев, 2005).

Северная часть Тихого океана (Северная Пацифика) представляет собой уникальный по экологическим условиям район, расположенный в двух различных климатических зонах: субарктической и умеренной. Эта часть океана характеризуется обширным шельфом. Конфигурация берегов, окаймляющих северную часть Тихого океана, оказывает влияние на схему существующих в этом районе течений, а также на проходящие здесь биологические процессы. Вся северная часть Тихого океана не имеет сколько-нибудь значительного пресноводного стока. Северозападная и северная части этого региона относительно мелководны. Тем не менее течения по 
краям мощных потоков и на границах теплых и холодных вод обеспечивают высокую продуктивность северо-западной и северной частей этого региона (Микулин, 2003).

Фауна рыб, обитающих в прибрежных морских водах северо-востока России (СВР), исключительно богата и разнообразна. Это один из наиболее продуктивных районов мира, дающий ежегодно свыше 2 млн т рыбопродукции. Вылов рыбных ресурсов в этом регионе приближается к 2 т с 1 км² поверхности моря (Борец, 1997).

В морях и внутренних водоемах СВР обитают более 500 видов морских, проходных и пресноводных рыб (Каталог..., 2000; Черешнев и др., 2001; Федоров и др., 2003). В прибрежных морских водах северо-востока России достоверно зарегистрированы 478 видов и подвидов рыбообразных и рыб, относящихся к трем классам, 20 отрядам и 63 семействам (Каталог ..., 2000; Датский, Андронов, 2007; Черешнев, 2008). Подавляющее число видов составляет морская ихтиофауна. Так, в Беринговом море обитает более 300 видов, в Охотском море, по разным оценкам, от 200 (в северной части) до 300 видов (в южной части) (Шмидт, 1904, 1950; Парин, 1968; Федоров, Парин, 1998; Каталог..., 2000). В морских прибрежных водах северо-востока России нерест и раннее развитие известны для 112 видов рыб. Из них около 30 видов выметывают пелагическую икру и более 70 видов - донную икру.

Согласно традиционной схеме зоогеографического районирования, исследуемый район принадлежит к умеренно-холодному (севернобореальному) комплексу климатических зон и включает палеарктическую область и Берингийскую переходную область (Берг, 1955; Дарлингтон, 1966; Никольский, 1974; Черешнев, 1998). Значительное широтное протяжение рассматриваемого района определяет многообразие видового состава ихтиофауны. Различие условий обитания также определяет многообразие особенностей размножения и раннего развития рыб.

Зоогеографическое районирование морских акваторий обычно производили по распространению бентосных организмов, поскольку они больше привязаны к определенным районам (Петряшев, 2005). Сведения по зоогеографии морских рыб северной части Тихого океана имеются в литературе (Кусакин, 1979). Есть данные по зоогеографическому районированию дальневосточных морей (Дьяков, 2009), где прикамчатские морские воды выделены в один, камчатский, район, и по зоогеографическому районированию нектона прикурильских и южно-камчатских вод (Иванов, Суханов, 2013). Известные зоогеографические характеристики основывались на распределении и обнаружении преимущественно взрослых рыб, что допускает возможность миграции или случайного заноса некоторых видов рыб в рассматриваемый район. Наиболее правильно было бы рассматривать зоогеографические характеристики рыб по местам их размножения и раннего развития. В связи с важностью изучения распределения рыб на ранних стадиях развития цель данной работы - рассмотреть зоогеографические характеристики морских рыб прикамчатских вод, основываясь на распределении ранних стадий их развития. Выяснение особенностей распределения рыб на ранних стадиях развития даст более точную картину географического распространения видов и позволит определить сходство или различие прилежащих к п-ову Камчатка морских районов по составу ихтиофауны.

\section{МАТЕРИАЛ И МЕТОДЫ}

Для биогеографического анализа использованы данные по раннему развитию рыб (икринки, личинки), собранные за период научных исследований с 1984 по 2003 г. в шельфовых районах Камчатки и смежных с ними морских водах (Охотское и Берингово моря, юго-восточное побережье Камчатки) при проведении съемок по учету численности икринок и личинок минтая и сельди и при гидробиологических съемках.

При проведении стандартных ихтиопланктонных съемок по учету численности икринок и личинок минтая для лова ихтиопланктона использовали ихтиопланктонную коническую сеть (ИКС-80) с диаметром входного отверстия 80 см и площадью входного отверстия $0.5 \mathrm{~m}^{2}$, изготовленную в сливной части из сита с шагом ячеи 0.55-0.56 мм. По стандартным сеткам станций в районах нереста промысловых рыб выполняли вертикальные ловы от дна до поверхности при глубине обычно до 200 м или от глубины 200 м до поверхности при больших глубинах. Как исключение, проводились ловы и на других горизонтах. Кроме ихтиопланктонных проб, использовали многочисленные экземпляры икринок, личинок и мальков, собранные при гидробиологических исследованиях, траловых съемках, прочих полевых сборах.

Для изучения географического распределения рыб морские воды, омывающие п-ов Камчатка, мы разделили на следующие районы: 1 - Север Охотского моря, 2 - Западная Камчатка, 3 - Южная Камчатка и Курильские острова, 4 - Восточная Камчатка, 5 - Юго-Запад Берингова моря, 6) Северо-Запад Берингова моря (рис. 1). Эти районы удобно выделять при морских планктонных и ихтиологических исследованиях, и они в данной работе рассматриваются как географические районы.

Зоогеографическая характеристика включает термины и обозначения, связанные с характером географического ареала. При наличии соответ- 


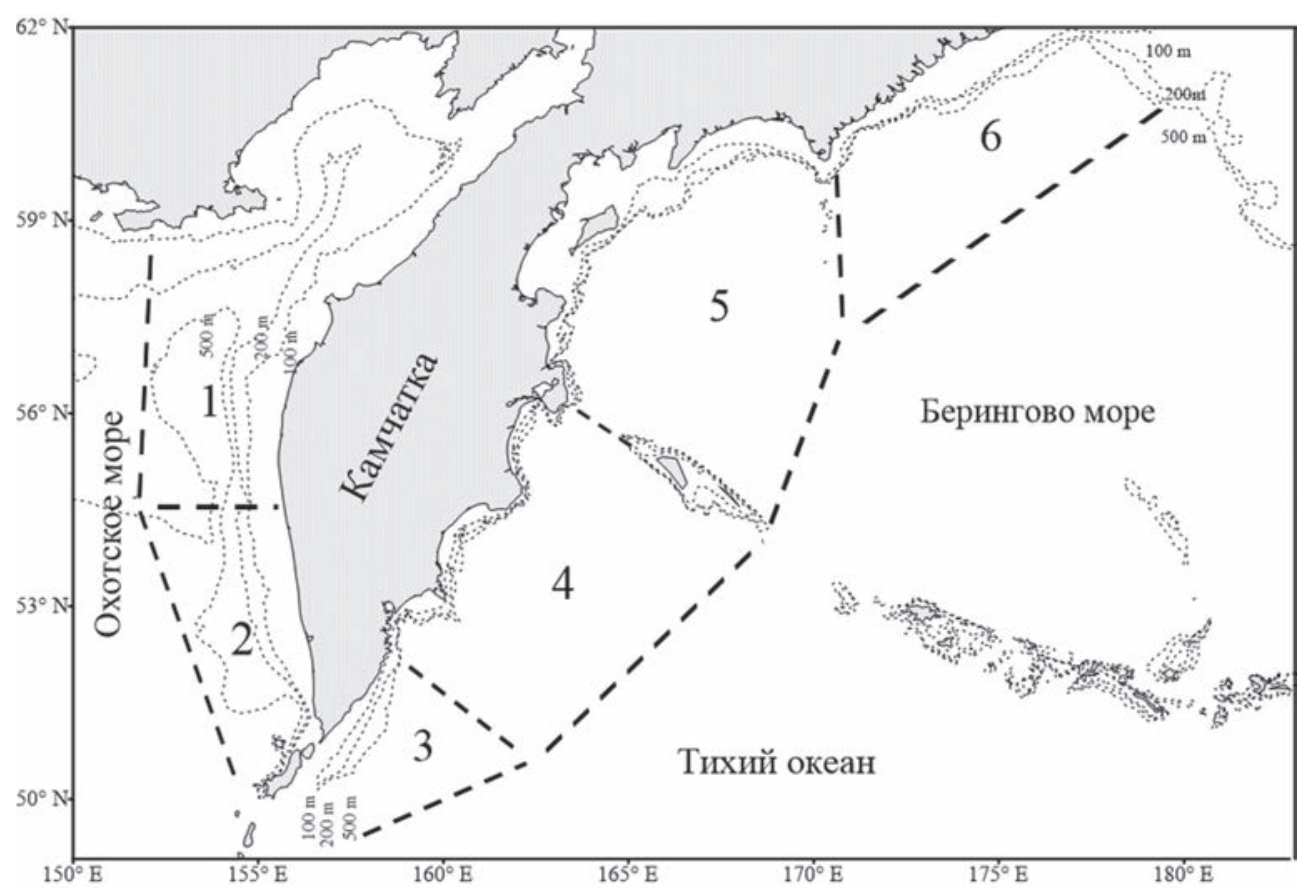

Рuc. 1. Схема, условная граница и районы исследований ранних стадий развития морских рыб: 1 - северная часть Охотского моря, 2 - Западная Камчатка, 3 - Южная Камчатка и Курильские острова, 4 - Восточная Камчатка, 5 - юго-западная часть Берингова моря, 6 - северо-западная часть Берингова моря

Fig. 1. Scheme, conventional boundary, and areas of researching marine fishes early stages: 1 - northern part of the Sea of Okhotsk, 2 - Western Kamchatka, 3 - Southern Kamchatka and Kuril Islands, 4 - Eastern Kamchatka, 5 - southwestern part of the Bering Sea, 6 - northwestern part of the Bering Sea

ствующих сведений тип ареала определялся по расположению репродуктивной основы ареала, в остальных случаях - по степени совпадения общего ареала таксона с перечисленными ниже известными его типами.

Границы между географическими районами в изучаемом регионе не совпадают с границами ареалов видов, поэтому выделение зоогеографических группировок является довольно условным. Биогеографическая граница между выделенными областями не является четкой по причине широкого распространения рассматриваемых видов. Тем не менее изменения ихтиофауны между географическими районами были выражены в виде коэффициента фаунистической общности (коэффициент Жаккара) (Елисеева, Рукавишников, 1977):

$$
\mathrm{K}_{\mathrm{j}}=c / a+b-c,
$$

где $c$ - количество видов, общих для первой и второй географических областей; $a-$ количество видов в первой сравниваемой географической области; $b$ - количество видов во второй сравниваемой географической области.

Чтобы охарактеризовать комплексы видов в каждом условном районе, для каждого такого района было определено количество обитающих там видов с известными ранними стадиями. Это количество сравнивали с общим количеством видов в двух сравниваемых районах.
Для обсуждения и обобщения материалов использовали литературные данные. Обширные сведения по репродуктивной биологии и раннему развитию морских рыб заимствованы из американских, японских и других источников (An Atlas..., 1988; Matarese et al., 1989; Григорьев, 2007, 2013). Зоогеографический статус видов определяли по Каталогу позвоночных Камчатки и сопредельных морских акваторий (2000). Систематическое положение видов дается с учетом современных ихтиологических баз данных (AquaMaps Data sources...; The World Register of Marine Species (WoRMS) http://www.marinespecies.org/index.php). Зоогеографические категории и биотопические группировки рассматривались в соответствии с принятыми в литературе представлениями и определялись с учетом имеющихся данных (Розенберг и др., 1999 ; Каталог..., 2000; Федоров и др., 2003). Для анализа таксономического разнообразия построена таблица, в каждой строке которой записан объект исследования (вид рыбы, таксон), а в столбцах размещаются данные по встречаемости на ранних стадиях развития.

\section{РЕЗУЛЬТАТЫ И ОБСУЖДЕНИЕ}

Для изучения зоогеографических характеристик морской ихтиофауны прикамчатских вод в настоящей работе предлагаются следующие 
типы ареалов морских рыб по А. П. Андрияшеву $(1939,1979)$ и Н. В. Парину (1979) с изменениями и дополнениями:

1. Арктический - включает окраинные арктические моря;

2. Арктическо-бореальный - северная часть Тихого океана и арктические моря;

3. Северно-бореальный - северная часть Охотского моря, северо-западная часть Берингова моря;

4. Умеренно-бореальный - Западная Камчатка, Восточная Камчатка, юго-западная часть Берингова моря, северные Курильские острова;

5. Южно-бореальный - южная часть Охотского моря, южные Курильские острова;

6. Субтропическо-бореальный - Японское море, Тихоокеанское побережье Японии.
На основании имеющихся сведений для морских вод, омывающих п-ов Камчатка, выделены три типа ареала происхождения и распространения видов:

1. Атланто-тихоокеанский - включает Атлантический и Тихий океаны;

2. Северо-тихоокеанский - включает ареал обитания видов, встречающихся как в приазиатских, так и в приамериканских водах северной части Тихого океана;

3. Северо-западно-тихоокеанский - включает ареал обитания видов, встречающихся только в приазиатских водах.

Районы постоянного обитания или возможной встречаемости рассматриваемых видов, разделенных по ареалам распространения, показаны на рис. 2.

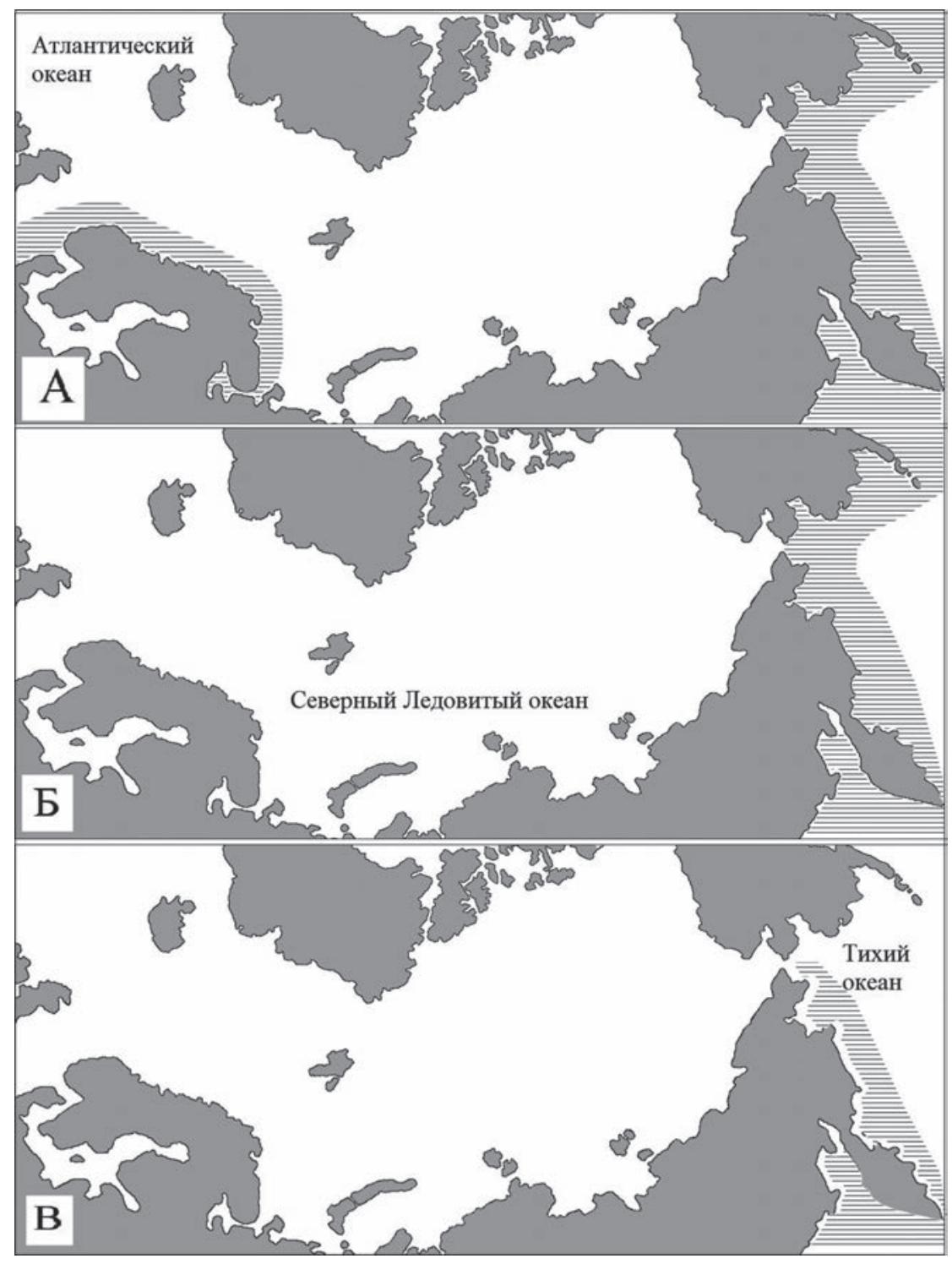

Рис. 2. Схема районов распространения морских рыб рассматриваемых видов (заштриховано): А - атлантотихоокеанских, Б - северо-тихоокеанских В - северо-западно-тихоокеанских

Fig. 2. Scheme of distribution areas of the discussed marine fish species (shaded): $\mathbf{A}$-Atlantic-Pacific species, $\mathbf{6}$ North-Pacific species, B - Northwest-Pacific species 
Для определения зоогеографического статуса отдельных видов составлен систематический список рыб, икринки и личинки которых могут встречаться в рассматриваемых районах (табл. 1).
Ихтиофауна морских вод СВР характеризуется смешанным обликом по отношению видов к солености, термическому режиму вод, а также по наиболее вероятным климатическим и географическим районам происхождения и распространения.

Таблица 1. Зоогеографический статус видов морских рыб прикамчатских вод в связи с распространением и встречаемость в условных географических районах на ранних стадиях развития

Table 1. Zoogeographic status of marine fish species in Kamchatka waters associated with their distribution areas and their occurrence in conventional geographic areas in early stages of development

\begin{tabular}{|c|c|c|c|c|c|}
\hline \multirow[b]{2}{*}{ Систематический список } & \multicolumn{2}{|c|}{$\begin{array}{l}\text { Присутствие } \\
\text { в планктоне }\end{array}$} & \multirow{2}{*}{$\begin{array}{c}\text { Зоогеогра- } \\
\text { фические } \\
\text { группиров- } \\
\text { ки видов }\end{array}$} & \multirow{2}{*}{$\begin{array}{c}\text { Виды } \\
\text { по аре- } \\
\text { алу } \\
\text { распро- } \\
\text { стране- } \\
\text { ния } \\
\end{array}$} & \multirow{2}{*}{$\begin{array}{c}\text { Условные } \\
\text { географиче- } \\
\text { ские районы } \\
\text { встречаемости }\end{array}$} \\
\hline & икринки & $\begin{array}{c}\text { ли- } \\
\text { чин- } \\
\text { ки } \\
\end{array}$ & & & \\
\hline 1 & 2 & 3 & 4 & 5 & 6 \\
\hline \multicolumn{6}{|c|}{$\begin{array}{l}\text { Отряд Clupeiformes - сельдеобразные } \\
\text { Семейство Clupeidae - сельдевые }\end{array}$} \\
\hline Clupea pallasii Valenciennes, 1847 - восточная сельдь & - & + & АБ & $\mathrm{CT}$ & $1,2,3,4,5,6$ \\
\hline \multicolumn{6}{|c|}{$\begin{array}{c}\text { Отряд Osmeriformes - корюшкообразные } \\
\text { Семейство Bathylagidae - батилаговые }\end{array}$} \\
\hline Bathylagus ochotensis Schmidt, 1938 - охотский батилаг & + & + & СБ & CT & $1,2,3,4,5,6$ \\
\hline Bathylagus pacificus Gilbert, 1890 - тихоокеанский батилаг & + & + & СБ & CT & $1,2,3,4,5,6$ \\
\hline $\begin{array}{l}\text { Leuroglossus schmidti Rass, } 1955 \text { - дальневосточная сереб- } \\
\text { рянка }\end{array}$ & + & + & СБ & CT & $1,2,3,4,5,6$ \\
\hline $\begin{array}{l}\text { Pseudobathylagus milleri (Jordan \& Gilbert, 1898) - батилаг } \\
\text { Миллера }\end{array}$ & + & + & СБ & CT & $1,2,3,4,5,6$ \\
\hline \multicolumn{6}{|c|}{ Семейство Microstomatidae - малоротковые } \\
\hline Nansenia candida Cohen, 1958 - белая нансения & + & + & БС & CT & 3,4 \\
\hline \multicolumn{6}{|c|}{ Семейство Opisthoproctidae - опистопроктовые } \\
\hline $\begin{array}{l}\text { Macropinna microstoma Chapman, } 1939 \text { - малоротая ма- } \\
\text { кропинна }\end{array}$ & + & + & СБ & CT & 3.4.5.6 \\
\hline \multicolumn{6}{|c|}{ Семейство Osmeridae - корюшковые } \\
\hline $\begin{array}{l}\text { Hуротеsus olidus (Pallas, 1814) - речная малоротая ко- } \\
\text { рюшка }\end{array}$ & - & + & АБ & CT & $1,2,3,4,5,6$ \\
\hline Mallotus villosus (Müller, 1776) - мойва & - & + & СБ & AT & $1,2,3,4,5,6$ \\
\hline $\begin{array}{l}\text { Osmerus mordax dentex Steindachner \& Kner, } 1870 \text { - зуба- } \\
\text { стая корюшка }\end{array}$ & - & + & АБ & CT & $1,2,3,4,5,6$ \\
\hline \multicolumn{6}{|c|}{$\begin{array}{l}\text { Отряд Gadiformes - трескообразные } \\
\text { Семейство Moridae - моровые }\end{array}$} \\
\hline $\begin{array}{l}\text { Laemonema longipes Schmidt, } 1938 \text { - длинноперая лемо- } \\
\text { нема }\end{array}$ & + & + & ЮБ & C3T & $4,5,6$ \\
\hline \multicolumn{6}{|c|}{ Семейство Gadidae - тресковые } \\
\hline Boreogadus saida (Lepechin, 1774) - сайка & - & + & A & AT & $1,2,3,4,5,6$ \\
\hline Eleginus gracilis (Tilesius, 1810) - навага & - & + & АБ & CT & $1,2,3,4,5,6$ \\
\hline Gadus chalcogrammus Pallas, 1814 - минтай & - & + & АБ & AT & $1,2,3,4,5,6$ \\
\hline Gadus macrocephalus Pallas, 1814 - большеглазая треска & + & + & АБ & AT & $1,2,3,4,5,6$ \\
\hline \multicolumn{6}{|c|}{$\begin{array}{c}\text { Семейство Macrouridae - долгохвостовые } \\
\text { Подсемейство Macrourinae }\end{array}$} \\
\hline $\begin{array}{l}\text { Albatrossia pectoralis (Gilbert, 1892) - малоглазый макру- } \\
\text { рус }\end{array}$ & + & + & УБ & CT & $1,2,3,4,5,6$ \\
\hline Coryphaenoides acrolepis (Bean, 1884) - черный макрурус & + & + & УБ & CT & $1,2,3,4,5,6$ \\
\hline $\begin{array}{l}\text { Coryphaenoides cinereus (Gilbert, 1896) - пепельный ма- } \\
\text { крурус }\end{array}$ & + & + & УБ & CT & $1,2,3,4,5,6$ \\
\hline
\end{tabular}


Продолжение табл. 1

\begin{tabular}{|c|c|c|c|c|c|}
\hline \multirow{2}{*}{ Систематический список } & \multicolumn{2}{|c|}{$\begin{array}{l}\text { Присутствие } \\
\text { в планктоне }\end{array}$} & \multirow{2}{*}{$\begin{array}{c}\text { Зоогеогра- } \\
\text { фические } \\
\text { группиров- } \\
\text { ки видов }\end{array}$} & \multirow{2}{*}{\begin{tabular}{|c|} 
Виды \\
по аре- \\
алу \\
распро- \\
стране- \\
ния \\
\end{tabular}} & \multirow{2}{*}{$\begin{array}{l}\text { Условные } \\
\text { географиче- } \\
\text { ские районы } \\
\text { встречаемости }\end{array}$} \\
\hline & икринки & $\begin{array}{c}\text { ли- } \\
\text { чин- } \\
\text { ки }\end{array}$ & & & \\
\hline 1 & 2 & 3 & 4 & 5 & 6 \\
\hline \multicolumn{6}{|c|}{$\begin{array}{c}\text { Отряд Gasterosteiformes - колюшкообразные } \\
\text { Семейство Gasterosteidae - колюшковые }\end{array}$} \\
\hline $\begin{array}{l}\text { Gasterosteus aculeatus Linnaeus, } 1758 \text { - трехиглая колюш- } \\
\text { ка }\end{array}$ & - & + & АБ & AT & $1,2,3,4,5,6$ \\
\hline $\begin{array}{l}\text { Pungitius pungitius (Linnaeus, 1758) - девятииглая колюш- } \\
\text { ка }\end{array}$ & - & + & АБ & AT & $1,2,3,4,5,6$ \\
\hline \multicolumn{6}{|c|}{$\begin{array}{c}\text { Отряд Scorpaeniformes - скорпенообразные } \\
\text { Подотряд Scorpaenoidei - скорпеновидные } \\
\text { Семейство Sebastidae - морские окуни } \\
\text { Подсемейство Sebastinae } \\
\end{array}$} \\
\hline $\begin{array}{l}\text { Sebastes melanostictus (Matsubara, 1934) - крапчатый } \\
\text { морской окунь }\end{array}$ & - & + & СБ & $\mathrm{CT}$ & $3,4,5,6$ \\
\hline $\begin{array}{l}\text { Sebastes alutus (Gilbert, 1890) - тихоокеанский морской } \\
\text { окунь }\end{array}$ & - & + & СБ & $\mathrm{CT}$ & $1,2,3,4,5,6$ \\
\hline Sebastes ciliatus (Tilesius, 1813) - бурый морской окунь & - & + & СБ & $\mathrm{CT}$ & $3,4,5,6$ \\
\hline $\begin{array}{l}\text { Sebastes polyspinis (Taranetz \& Moiseev, 1933) - многоиг- } \\
\text { лый морской окунь }\end{array}$ & - & + & СБ & $\mathrm{CT}$ & $3,4,5,6$ \\
\hline \multicolumn{6}{|c|}{ Подсемейство Sebastolobinae } \\
\hline $\begin{array}{l}\text { Sebastolobus alascanus Bean, } 1890 \text { - аляскинский шипо- } \\
\text { щек }\end{array}$ & - & + & СБ & $\mathrm{CT}$ & $2,3,4,5,6$ \\
\hline \multicolumn{6}{|c|}{$\begin{array}{c}\text { Подотряд Anoplopomatoidei - аноплопомовидные } \\
\text { Семейство Anoplopomatidae - аноплопомовые }\end{array}$} \\
\hline Anoplopoma fimbria (Pallas, 1814) - угольная рыба & + & + & УБ & $\mathrm{CT}$ & $2,3,4,5,6$ \\
\hline \multicolumn{6}{|c|}{$\begin{array}{c}\text { Подотряд Hexagrammoidei - терпуговидные } \\
\text { Семейство Hexagrammidae - терпуговые } \\
\text { Подсемейство Hexagramminae }\end{array}$} \\
\hline $\begin{array}{l}\text { Hexagrammos lagocephalus (Pallas, 1810) - зайцеголовый тер- } \\
\text { пуг }\end{array}$ & - & + & УБ & $\mathrm{CT}$ & $1,2,3,4,5,6$ \\
\hline Hexagrammos octogrammus (Pallas, 1814) - бурый терпуг & - & + & УБ & $\mathrm{CT}$ & $1,2,3,4,5,6$ \\
\hline Hexagrammos stelleri Tilesius, 1810 - пятнистый терпуг & - & + & СБ & $\mathrm{CT}$ & $1,2,3,4,5,6$ \\
\hline $\begin{array}{l}\text { Pleurogrammus monopterygius (Pallas, 1810) - северный } \\
\text { одноперый терпуг }\end{array}$ & - & + & СБ & $\mathrm{CT}$ & $1,2,3,4,5,6$ \\
\hline \multicolumn{6}{|c|}{$\begin{array}{c}\text { Подотряд Cottoidei - рогатковидные } \\
\text { Семейство Cottidae - рогатковые }\end{array}$} \\
\hline Enophris diceraus (Pallas, 1787) - двурогий бычок & -1 & + & УБ & $\mathrm{CT}$ & $1,2,3,4,5,6$ \\
\hline $\begin{array}{l}\text { Gymnocanthus detrisus Gilbert \& Burke, } 1912 \text { - широколобый } \\
\text { шлемоносец }\end{array}$ & - & + & УБ & $\mathrm{CT}$ & $1,2,3,4,5,6$ \\
\hline $\begin{array}{l}\text { Gymnocanthus pistilliger (Pallas, 1814) - нитчатый шлемо- } \\
\text { носец }\end{array}$ & - & + & УБ & $\mathrm{CT}$ & $1,2,3,4,5,6$ \\
\hline $\begin{array}{l}\text { Gymnocanthus tricuspis (Reinhardt, 1830) - арктический } \\
\text { шлемоносец }\end{array}$ & - & + & A & $\mathrm{CT}$ & 6 \\
\hline $\begin{array}{l}\text { Hemilepidotus gilberti Jordan \& Starks, } 1904 \text { - пестрый } \\
\text { получешуйник }\end{array}$ & - & + & УБ & $\mathrm{CT}$ & $1,2,3,4,5,6$ \\
\hline $\begin{array}{l}\text { Hemilepidotus hemilepidotus (Tilesius, 1811) - пятнистый } \\
\text { получешуйник }\end{array}$ & - & + & СБ & $\mathrm{CT}$ & 5,6 \\
\hline $\begin{array}{l}\text { Heтilepidotus jordani Bean, 1881- белобрюхий получе- } \\
\text { шуйник }\end{array}$ & - & + & УБ & $\mathrm{CT}$ & $1,2,3,4,5,6$ \\
\hline $\begin{array}{l}\text { Hemilepidotus zapus Gilbert \& Burke, } 1912 \text { - чешуехво- } \\
\text { стый получешуйник }\end{array}$ & - & + & ЮБ & $\mathrm{CT}$ & 3 \\
\hline $\begin{array}{l}\text { Megalocottus platycephalus (Pallas, 1814) - дальневосточная } \\
\text { широколобка }\end{array}$ & - & + & АБ & $\mathrm{CT}$ & $1,2,3,4,5,6$ \\
\hline
\end{tabular}


Продолжение табл. 1

\begin{tabular}{|c|c|c|c|c|c|}
\hline \multirow{2}{*}{ Систематический список } & \multicolumn{2}{|c|}{$\begin{array}{l}\text { Присутствие } \\
\text { в планктоне }\end{array}$} & \multirow{2}{*}{$\begin{array}{c}\text { Зоогеогра- } \\
\text { фические } \\
\text { группиров- } \\
\text { ки видов }\end{array}$} & \multirow{2}{*}{\begin{tabular}{|c|} 
Виды \\
по аре- \\
алу \\
распро- \\
стране- \\
ния \\
\end{tabular}} & \multirow{2}{*}{$\begin{array}{c}\text { Условные } \\
\text { географиче- } \\
\text { ские районы } \\
\text { встречаемости }\end{array}$} \\
\hline & икринки & $\begin{array}{c}\text { ли- } \\
\text { чин- } \\
\text { ки } \\
\end{array}$ & & & \\
\hline 1 & 2 & 3 & 4 & 5 & 6 \\
\hline Myoхосерhalus jaok (Cuvier, 1829) - керчак-яок & - & + & УБ & $\mathrm{CT}$ & $1,2,3,4,5,6$ \\
\hline $\begin{array}{l}\text { Myохосерhalus polyacanthocephalus (Pallas, 1814) - многоиг- } \\
\text { лый керчак }\end{array}$ & - & + & УБ & $\mathrm{CT}$ & $1,2,3,4,5,6$ \\
\hline Myохосерhalus stelleri Tilesius, 1811 - мраморный керчак & - & + & СБ & CT & $1,2,3,4,5,6$ \\
\hline \multicolumn{6}{|c|}{ Семейство Hemitripteridae - волосатковые } \\
\hline Blepsias bilobus Cuvier, 1829 - двулопастной бычок & \begin{tabular}{|l|}
- \\
\end{tabular} & + & СБ & $\mathrm{CT}$ & $1,2,3,4,5,6$ \\
\hline Blepsias cirrhosus (Pallas, 1814) - трехлопастной бычок & - & + & СБ & CT & $1,2,3,4,5,6$ \\
\hline Hemitripterus villosus (Pallas, 1814) - бычок-ворон & - & + & СБ & CT & $1,2,3,4,5,6$ \\
\hline \multicolumn{6}{|c|}{ Семейство Psychrolutidae - психролютовые } \\
\hline Dasycottus setiger Bean, 1890 - щетинистый бычок & \begin{tabular}{|l|}
- \\
\end{tabular} & + & УБ & $\mathrm{CT}$ & $1,2,3,4,5,6$ \\
\hline $\begin{array}{l}\text { Gilbertidia sigalutes (Jordan \& Starks, 1895) - мягкий бы- } \\
\text { чок }\end{array}$ & - & + & СБ & CT & $1,2,3,4,5,6$ \\
\hline Malacocottus zonurus Bean, 1890 - черноперый бычок & - & + & УБ & CT & $1,2,3,4,5,6$ \\
\hline $\begin{array}{l}\text { Psychrolutes paradoxus Günther, } 1861 \text { - психролют удиви- } \\
\text { тельный }\end{array}$ & - & + & УБ & $\mathrm{CT}$ & $1,2,3,4,5,6$ \\
\hline \multicolumn{6}{|c|}{$\begin{array}{c}\text { Семейство Agonidae - лисичковые } \\
\text { Подсемейство Agoninae }\end{array}$} \\
\hline $\begin{array}{l}\text { Podothecus accipenserinus (Tilesius, 1813) - многоусая ли- } \\
\text { сичка }\end{array}$ & - & + & СБ & $\mathrm{CT}$ & $2,3,4,5,6$ \\
\hline $\begin{array}{l}\text { Podothecus sturioides (Guichenot, 1869) - дальневосточная } \\
\text { лисичка }\end{array}$ & - & + & ЮБ & C3T & $1,2,3,4$ \\
\hline $\begin{array}{l}\text { Sarritor leptorhynchus (Gilbert, 1896) - тонкорылая лисич- } \\
\text { ка }\end{array}$ & - & + & СБ & $\mathrm{CT}$ & $2,3,4,5,6$ \\
\hline \multicolumn{6}{|c|}{ Подсемейство Anoplagoninae } \\
\hline $\begin{array}{l}\text { Aspidophoroides monopterygius (Bloch, 1786) - тихоокеанский } \\
\text { щитонос }\end{array}$ & - & + & СБ & $\mathrm{CT}$ & $1,2,3,4,5,6$ \\
\hline \multicolumn{6}{|c|}{ Подсемейство Bathyagoninae } \\
\hline $\begin{array}{l}\text { Bathyagonus nigripinnis Gilbert, } 1890 \text { - черноперая лисич- } \\
\text { ка }\end{array}$ & - & + & СБ & $\mathrm{CT}$ & 3.4.5.6 \\
\hline \multicolumn{6}{|c|}{ Подсемейство Brachyopsinae } \\
\hline $\begin{array}{l}\text { Occella dodecaedron (Tilesius, 1813) - двенадцатигранная } \\
\text { лисичка }\end{array}$ & - & + & СБ & $\mathrm{CT}$ & $1,2,3,4,5,6$ \\
\hline \multicolumn{6}{|c|}{ Подсемейство Hypsagoninae } \\
\hline $\begin{array}{l}\text { Hypsagonus quadricornis Valenciennes, 1829) - северный } \\
\text { гипсагон }\end{array}$ & - & + & СБ & $\mathrm{CT}$ & $1,2,3,4,5,6$ \\
\hline Percis japonicus (Pallas, 1769) - японская лисичка & - & + & СБ & CT & $1,2,3,4,5,6$ \\
\hline Leptagonus decagonus - длинноусая лисичка & \begin{tabular}{|l|}
- \\
\end{tabular} & + & АБ & $\mathrm{CT}$ & 1.2 .3 .5 .6 \\
\hline \multicolumn{6}{|c|}{ Семейство Cyclopteridae - круглоперые } \\
\hline Aptocyclus ventricosus (Pallas, 1769) - рыба-лягушка & \begin{tabular}{|l|l}
- & \\
&
\end{tabular} & + & УБ & CT & $1,2,3,4,5,6$ \\
\hline $\begin{array}{l}\text { Eumicrotremus orbis (Günther, 1861) - шаровидный круг- } \\
\text { лопер }\end{array}$ & - & + & СБ & $\mathrm{CT}$ & $2,3,4,5,6$ \\
\hline \multicolumn{6}{|c|}{ Семейство Liparidae - липаровые } \\
\hline Liparis brashnikovi Soldatov, 1930 - липарис Бражникова & \begin{tabular}{|l|}
- \\
\end{tabular} & + & СБ & C3T & 4 \\
\hline Liparis fabricii Krøyer, 1847 - липарис Фабриция & - & + & $\mathrm{A}$ & CT & 6 \\
\hline Liparis greeni (Jordan \& Starks, 1895) - липарис Грина & - & + & УБ & C3T & 4 \\
\hline Liparis latifrons Schmidt, 1950 - полосатый липарис & - & + & УБ & $\mathrm{C} 3 \mathrm{~T}$ & 1.2 .4 \\
\hline Liparis ochotensis Schmidt, 1904 - охотский липарис & - & + & УБ & $\mathrm{CT}$ & $1,2,3,4,5,6$ \\
\hline
\end{tabular}


Продолжение табл. 1

\begin{tabular}{|c|c|c|c|c|c|}
\hline \multirow{2}{*}{ Систематический список } & \multicolumn{2}{|c|}{$\begin{array}{l}\text { Присутствие } \\
\text { в планктоне }\end{array}$} & \multirow{2}{*}{$\begin{array}{c}\text { Зоогеогра- } \\
\text { фические } \\
\text { группиров- } \\
\text { ки видов }\end{array}$} & \multirow{2}{*}{$\begin{array}{c}\text { Виды } \\
\text { по аре- } \\
\text { алу } \\
\text { распро- } \\
\text { стране- } \\
\text { ния }\end{array}$} & \multirow{2}{*}{$\begin{array}{l}\text { Условные } \\
\text { географиче- } \\
\text { ские районы } \\
\text { встречаемости }\end{array}$} \\
\hline & икринки & $\begin{array}{c}\text { ли- } \\
\text { чин- } \\
\text { ки }\end{array}$ & & & \\
\hline 1 & 2 & 3 & 4 & 5 & 6 \\
\hline $\begin{array}{l}\text { Nectoliparis pelagicus Gilbert \& Burke, } 1912 \text { - пелагический мор- } \\
\text { ской слизень }\end{array}$ & - & + & УБ & C3T & $1,2,3,4,5,6$ \\
\hline $\begin{array}{l}\text { Rhinoliparis barbulifer Gilbert, } 1896 \text { - многоусый морской } \\
\text { слизень }\end{array}$ & - & + & СБ & C3T & $1,2,3,4,5,6$ \\
\hline \multicolumn{6}{|c|}{$\begin{array}{c}\text { Отряд Perciformes - окунеобразные } \\
\text { Подотряд Zoarcoidei - бельдюговидные } \\
\text { Семейство Bathymasteridae - батимастеровые }\end{array}$} \\
\hline $\begin{array}{l}\text { Bathymaster signatus Cope, } 1873 \text { - обозначенный батима- } \\
\text { стер }\end{array}$ & - & + & СБ & $\mathrm{CT}$ & $2,3,4,5,6$ \\
\hline \multicolumn{6}{|c|}{ Семейство Pholidae - маслюковые } \\
\hline $\begin{array}{l}\text { Pholis fasciata (Bloch \& Schneider, 1801) - полосатый мас- } \\
\text { люк }\end{array}$ & - & + & АБ & $\mathrm{CT}$ & $1,2,3,4,5,6$ \\
\hline \multicolumn{6}{|c|}{$\begin{array}{l}\text { Семейство Stichaeidae - стихеевые } \\
\text { Подсемейство Chirolophinae }\end{array}$} \\
\hline $\begin{array}{l}\text { Bryozoichthys lysimus (Jordan \& Snyder, 1902) - длинноперая } \\
\text { мшанковая собачка }\end{array}$ & - & + & УБ & C3T & $1,3,4,5,6$ \\
\hline $\begin{array}{l}\text { Chirolophis snyderi (Taranetz, 1938) - северная мохнатоголо- } \\
\text { вая собачка }\end{array}$ & - & + & УБ & C3T & $1,2,3,4,5,6$ \\
\hline \multicolumn{6}{|c|}{ Подсемейство Lumpeninae } \\
\hline $\begin{array}{l}\text { Acantholumpenus mackayi (Gilbert, 1896) - колючий люм- } \\
\text { пен }\end{array}$ & - & + & УБ & C3T & 1.2 .4 \\
\hline Leptoclinus maculatus (Fries, 1838) - пятнистый люмпен & - & + & АБ & $\mathrm{CT}$ & $1,2,3,4,5,6$ \\
\hline $\begin{array}{l}\text { Lumpenella longirostris (Evermann \& Goldsborough, 1907)- } \\
\text { длиннорылый люмпен }\end{array}$ & - & + & УБ & AT & $1,2,3,4,5,6$ \\
\hline Lumpenus fabricii Reinhardt, 1836 - люмпен Фабриция & - & + & АБ & $\mathrm{CT}$ & 6 \\
\hline $\begin{array}{l}\text { Lumpenus sagitta Wilimovsky, } 1956 \text { - стреловидный люм- } \\
\text { пен }\end{array}$ & - & + & АБ & CT & $1,2,3,4,5,6$ \\
\hline \multicolumn{6}{|c|}{ Подсемейство Opisthocentrinae } \\
\hline $\begin{array}{l}\text { Opisthocentrus ocellatus (Tilesius, 1811) - глазчатый опи- } \\
\text { стоцентр }\end{array}$ & - & + & УБ & C3T & $1,2,3,4,5,6$ \\
\hline \multicolumn{6}{|c|}{ Подсемейство Stichaeinae } \\
\hline $\begin{array}{l}\text { Ernogrammus hexagrammus (Schlegel, 1845) - шестили- } \\
\text { нейный стихей }\end{array}$ & - & + & ЮБ & C3T & 3 \\
\hline $\begin{array}{l}\text { Stichaeus punctatus punctatus (Fabricius, 1780) - пятнистый } \\
\text { стихей }\end{array}$ & - & + & АБ & AT & $1,2,3,4,5,6$ \\
\hline \multicolumn{6}{|c|}{ Подсемейство Xiphisterinae } \\
\hline Alectrias alectrolophus (Pallas, 1814) - морской петушок & - & + & УБ & C3T & $1,2,3,4,5,6$ \\
\hline \multicolumn{6}{|c|}{ Семейство Anarhichadidae - зубатковые } \\
\hline Anarhichas orientalis Pallas, 1814 - восточная зубатка & - & + & УБ & C3T & $1,2,3,4,5,6$ \\
\hline \multicolumn{6}{|c|}{ Семейство Ptilichthyidae - птилихтовые } \\
\hline Ptilichthys goodie Bean, 1881 - птилихт & - & + & УБ & $\mathrm{CT}$ & $1,2,3,4,5$ \\
\hline \multicolumn{6}{|c|}{ Семейство Zaproridae - запроровые } \\
\hline Zaprora silenus Jordan, 1896 - запрора & - & + & УБ & $\mathrm{CT}$ & $2,3,4,5,6$ \\
\hline
\end{tabular}


Окончание табл. 1

\begin{tabular}{|c|c|c|c|c|c|}
\hline \multirow[b]{2}{*}{ Систематический список } & \multicolumn{2}{|c|}{$\begin{array}{l}\text { Присутствие } \\
\text { в планктоне }\end{array}$} & \multirow{2}{*}{$\begin{array}{c}\text { Зоогеогра- } \\
\text { фические } \\
\text { группиров- } \\
\text { ки видов }\end{array}$} & \multirow{2}{*}{$\begin{array}{c}\text { Виды } \\
\text { по аре- } \\
\text { алу } \\
\text { распро- } \\
\text { стране- } \\
\text { ния }\end{array}$} & \multirow{2}{*}{$\begin{array}{c}\text { Условные } \\
\text { географиче- } \\
\text { ские районы } \\
\text { встречаемости }\end{array}$} \\
\hline & икринки & $\begin{array}{c}\text { ли- } \\
\text { чин- } \\
\text { ки }\end{array}$ & & & \\
\hline 1 & 2 & 3 & 4 & 5 & 6 \\
\hline \multicolumn{6}{|c|}{ Семейство Zoarcidae - бельдюговые } \\
\hline Zoarces elongatus Kner, 1868 - бельдюга & - & + & УБ & C3T & 1.2 .3 \\
\hline \multicolumn{6}{|c|}{$\begin{array}{l}\text { Подотряд Trachinoidei - песчанковидные } \\
\text { Семейство Ammodytidae - песчанковые }\end{array}$} \\
\hline Ammodytes hexapterus Pallas, 1814 - песчанка & - & + & АБ & $\mathrm{CT}$ & $1,2,3,4,5,6$ \\
\hline \multicolumn{6}{|c|}{ Семейство Trichodontidae - волосозубовые } \\
\hline Trichodon trichodon (Tilesius, 1813) - северный волосозуб & - & + & СБ & CT & $1,2,3,4,5,6$ \\
\hline \multicolumn{6}{|c|}{$\begin{array}{c}\text { Подотряд Icosteoidei - тряпичниковидные } \\
\text { Семейство Icosteidae - тряпичниковые }\end{array}$} \\
\hline Icosteus aenigmaticus Lockington, 1880 - тряпичник & - & + & УБ & CT & $1,2,3,4,5,6$ \\
\hline \multicolumn{6}{|c|}{$\begin{array}{c}\text { Отряд Pleuronectiformes - камбалообразные } \\
\text { Семейство Pleuronectidae - камбаловые }\end{array}$} \\
\hline $\begin{array}{l}\text { Atheresthes evermanni Jordan \& Starks, } 1904 \text { - азиатский } \\
\text { стрелозубый палтус }\end{array}$ & + & + & УБ & C3T & $1,2,3,4,5,6$ \\
\hline $\begin{array}{l}\text { Atheresthes stomias (Jordan \& Gilbert, 1880) - американский } \\
\text { стрелозубый палтус }\end{array}$ & + & + & УБ & CT & $2,3,4,5,6$ \\
\hline $\begin{array}{l}\text { Embassichthys bathybius (Gilbert, 1890) - глубинная кам- } \\
\text { бала }\end{array}$ & + & + & УБ & $\mathrm{CT}$ & $3,4,5,6$ \\
\hline Glyptocephalus stelleri (Schmidt, 1904) - малорот Стеллера & + & + & УБ & $\mathrm{CT}$ & $1,2,3$ \\
\hline $\begin{array}{l}\text { Glyptocephalus zachirus Lockington, } 1879 \text { - длинноперый } \\
\text { малорот }\end{array}$ & + & + & УБ & $\mathrm{CT}$ & $4,5,6$ \\
\hline $\begin{array}{l}\text { Hippoglossoides dubius Schmidt, } 1904 \text { - южная палтусо- } \\
\text { видная камбала }\end{array}$ & + & + & УБ & CT & 3 \\
\hline $\begin{array}{l}\text { Hippoglossoides elassodon Jordan \& Gilbert, } 1880 \text { - узкозу- } \\
\text { бая палтусовидная камбала }\end{array}$ & + & + & УБ & CT & $1,2,3,4,5,6$ \\
\hline $\begin{array}{l}\text { Hippoglossoides robustus Gill \& Townsend, } 1897 \text { - северная } \\
\text { палтусовидная камбала }\end{array}$ & + & + & АБ & $\mathrm{CT}$ & $1,2,3,4,5,6$ \\
\hline $\begin{array}{l}\text { Hippoglossus stenolepis Schmidt, } 1904 \text { - тихоокеанский } \\
\text { белокорый палтус }\end{array}$ & + & + & УБ & $\mathrm{CT}$ & $1,2,3,4,5,6$ \\
\hline $\begin{array}{l}\text { Lepidopsetta polyxystra Orr \& Matarese, } 2000 \text { - северная } \\
\text { двухлинейная камбала }\end{array}$ & - & + & СБ & CT & $1,2,3,4,5,6$ \\
\hline Limanda aspera (Pallas, 1814) - желтоперая камбала & + & + & УБ & CT & $1,2,3,4,5,6$ \\
\hline Limanda sakhalinensis Hubbs, 1915 - сахалинская камбала & + & + & УБ & $\mathrm{CT}$ & $1,2,3,4,5,6$ \\
\hline Limanda proboscidea Gilbert, 1896 - хоботная камбала & + & + & УБ & C3T & $1,2,3,4,5,6$ \\
\hline $\begin{array}{l}\text { Microstomus pacificus (Lockington, 1879) - американский } \\
\text { малорот }\end{array}$ & + & + & УБ & $\mathrm{C} 3 \mathrm{~T}$ & 5,6 \\
\hline Platichthys stellatus (Pallas, 1787) - звездчатая камбала & + & + & АБ & $\mathrm{CT}$ & $1,2,3,4,5,6$ \\
\hline Liopsetta glacialis (Pallas, 1776) - полярная камбала & + & + & АБ & $\mathrm{CT}$ & $1,2,3,4,5,6$ \\
\hline $\begin{array}{l}\text { Pleuronectes quadrituberculatus Pallas, } 1814 \text { - желтобрюхая } \\
\text { камбала }\end{array}$ & + & + & УБ & CT & $1,2,3,4,5,6$ \\
\hline $\begin{array}{l}\text { Reinhardtius hippoglossoides (Walbaum, 1792) - черный } \\
\text { палтус }\end{array}$ & + & + & УБ & $\mathrm{CT}$ & $1,2,3,4,5,6$ \\
\hline
\end{tabular}

Примечание. Зоогеографические группировки видов: А - Арктическая, АБ - Арктическо-бореальная, СБ Северно-бореальная, УБ - Умеренно-бореальная, ЮБ - Южно-бореальная, БС - Субтропическо-бореальные. Виды по распространению: АТ - Атланто-тихоокеанский, СТ - Северо-тихоокеанский, СЗТ - Северо-западно-тихоокеанский. Условные географические районы встречаемости: 1 - северная часть Охотского моря, 2 - Западная Камчатка, 3 - Южная Камчатка и Курильские острова, 4 - Восточная Камчатка, 5 - Юго-западная часть Берингова моря, 6 - Северо-западная часть Берингова моря. 
Для рыб с нерестом и ранним развитием в море по ареалам обитания преобладают виды северо-тихоокеанского распространения (79.6\%). Значительно меньше в этом районе видов северозападно-тихоокеанскогораспространения (16.7\%) (рис. 3, А). В качестве примера таких рыб можно привести некоторых представителей семейств Liparidae, Cyclopteridae, Zoarcidae и др. Меньше всего рыб атланто-тихоокеанского распространения. Это традиционно атланто-тихоокеанские виды (например, Stichaeus punctatus и Lumpenella longirostris). Кроме того, циркумполярные виды Gasterosteus aculeatus и Pungitius pungitius. В соответствии с современными представлениями о систематике рыб к атланто-тихоокеанским видам можно отнести большеглазую треску Gadus macrocephalus, синонимом которой признаны беломорская треска G. callarias marisalbi Derjugin, 1920 и гренландская треска G. ogac Richardson, 1836 , а также минтая, единичные поимки которого под видом G. finnmarchicus (Koefoed, 1956) имели место на границе Баренцева и Норвежского морей и который в настоящее время признан одним видом с тихоокеанским минтаем под общим названием Gadus chalcogrammus (Coulson et al., 2006; Eschmeyer, 2012; Григорьев, Седова, 2016; The World Register of Marine (WoRMS) http://www.marinespecies.org/index.phpSpecies...).

При разделении рыб на группы по зоогеографическим характеристикам преобладают северно-бореальные и умеренно-бореальные виды, к которым относится большинство типично морских рыб из отрядов скорпенообразных, окунеобразных и камбалообразных. Беднее по числу видов арктические и арктическобореальные виды. Как исключение, встречаются южно-бореальные и субтропическо-бореальные виды (см. рис. 3, Б).

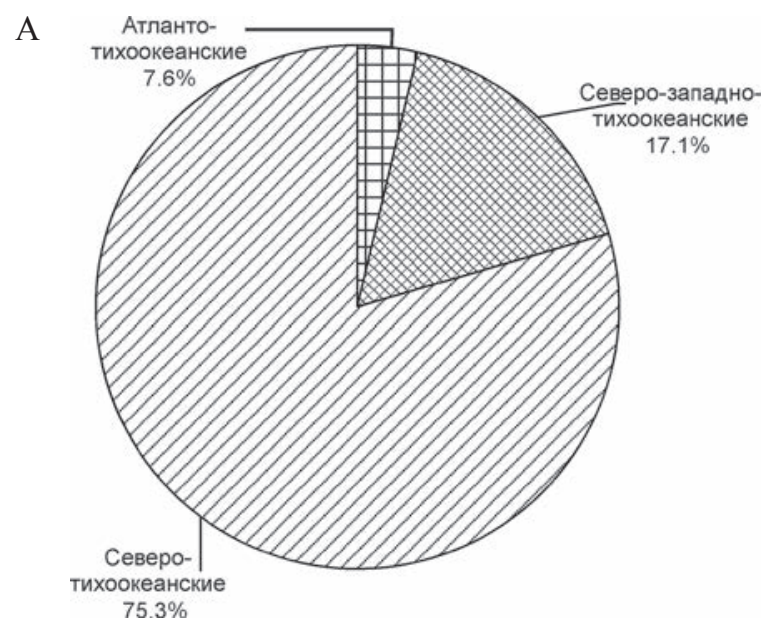

Морские рыбы северо-тихоокеанского распространения доминируют как по разнообразию зоогеографических группировок, так и по численности видов в ареалах их обитания. Среди них преобладают умеренно-бореальные, севернобореальные и аркто-бореальные. Среди видов западно-тихоокеанского распространения также преобладают умеренно-бореальные виды. Наименьшую долю составляют виды атлантическотихоокеанского распространения. В целом преобладают умеренно-бореальные (43.8\%), севернобореальные $(30.4 \%)$ и арктическо-бореальные $(18.0 \%)$. Самая малочисленная группа - это субтропическо-бореальные виды, составляющие приблизительно $1 \%$ от всех рассматриваемых видов (табл. 2).

В водах, омывающих Камчатку, обитает комплекс видов, различающихся по ареалу распространения и по принадлежности к зоогеографическим комплексам. На рис. 4 показано сравнение условных географических районов по количеству видов: окружности - количество видов, отмеченных на ранних стадиях развития в каждом районе исследований; эллипсы - сравнительное количество общих видов в районах, соединенных стрелками.

Наибольшее количество видов рыб отмечено в северо-западной части Берингова моря, наименьшее - в северной части Охотского моря. Между этими районами наблюдается наименьшее число общих видов. На приведенной схеме видно, что количество общих видов между восточными и западными условными районами на пять видов меньше, чем количество видов в западных районах, а количество общих видов между условными районами из одного моря на три вида меньше, чем в сравниваемом районе с меньшим числом видов.

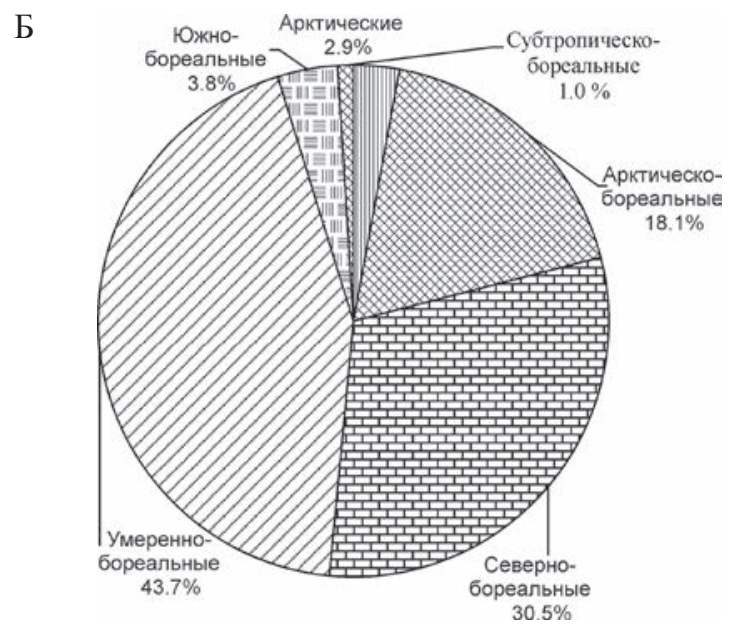

Рис. 3. Процентное соотношение видов морских рыб прикамчатских вод с известными ранними стадиями развития в зависимости от происхождения (А) и распределение их по зоогеографическим группировкам (Б)

Fig. 3. Percentage of species of marine fishes of Kamchatka waters with known early stages of development depending on their origin (A), and their distribution according to zoogeographic groups (Б) 
Таблица 2. Распределение видов морских рыб прикамчатских вод с известными ранними стадиями развития по районам обитания в зависимости от распространения зоогеографических группировок Table 2. Distribution of marine fish species with known early stages of development in Kamchatka waters according to their habitats, depending on distribution of zoogeographic groups

\begin{tabular}{|c|c|c|c|}
\hline Виды по распространению & $\begin{array}{c}\text { Зоогеографический статус видов } \\
\text { (по Андрияшеву, 1939) }\end{array}$ & $\begin{array}{c}\text { Количество } \\
\text { видов }\end{array}$ & Доля в ихтиофауне, $\%$ \\
\hline \multirow{4}{*}{ Атланто-тихоокеанские } & Арктические & 1 & 1.0 \\
\hline & Арктическо-бореальные & 5 & 4.8 \\
\hline & Северно-бореальные & 1 & 1.0 \\
\hline & Умеренно-бореальные & 1 & 1.0 \\
\hline \multirow{3}{*}{$\begin{array}{l}\text { Северо-западно-тихоокеан- } \\
\text { ские }\end{array}$} & Северно-бореальные & 2 & 1.9 \\
\hline & Умеренно-бореальные & 13 & 12.4 \\
\hline & Южно-бореальные & 3 & 2.9 \\
\hline \multirow{6}{*}{ Северо-тихоокеанские } & Арктические & 2 & 1.9 \\
\hline & Арктическо-бореальные & 14 & 13.2 \\
\hline & Северно-бореальные & 29 & 27.5 \\
\hline & Умеренно-бореальные & 32 & 30.4 \\
\hline & Южно-бореальные & 1 & 1.0 \\
\hline & Субтропическо-бореальные & 1 & 1.0 \\
\hline
\end{tabular}

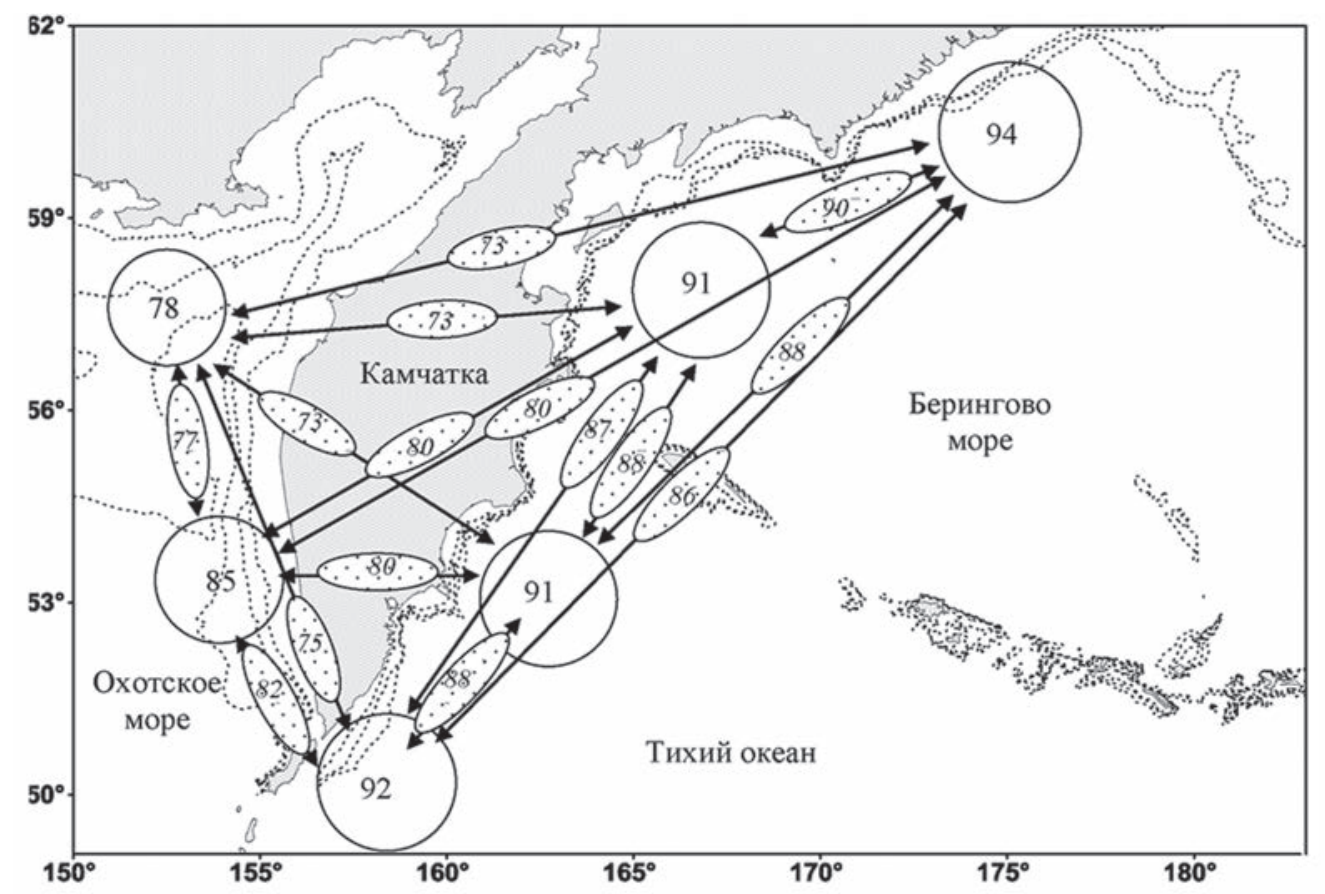

Рuc. 4. Сравнительное количество видов морских рыб с известными ранними стадиями развития по районам исследований в прикамчатских водах и сходство видов в этих районах (пояснения в тексте)

Fig. 4. Comparative number of marine fish species with known early stages of development by researched areas of Kamchatka waters and the species similarity in these areas (for explanations, see the text)

Для сравнения сходства ихтиофауны в рассматриваемых районах в морских водах, омывающих Камчатку, был рассчитан коэффициент фаунистической общности видов (Жаккара) (рис. 5).

Сходство видов морских рыб, обитающих в рассматриваемых условных географических районах, довольно высокое (значение коэффициента фаунистической общности приближается к единице). Этот коэффициент позволяет выде- лить районы с наиболее близким видовым составом ихтиофауны. Это будут: 1 - север Охотского моря и Западная Камчатка; 2 - Восточная Камчатка и западная часть Берингова моря; 3 - Южная Камчатка с северными Курильскими островами и Восточная Камчатка. Вполне естественно, что районы с наиболее близким видовым составом ихтиофауны оказались смежными по своему географическому положению. Наиболь- 


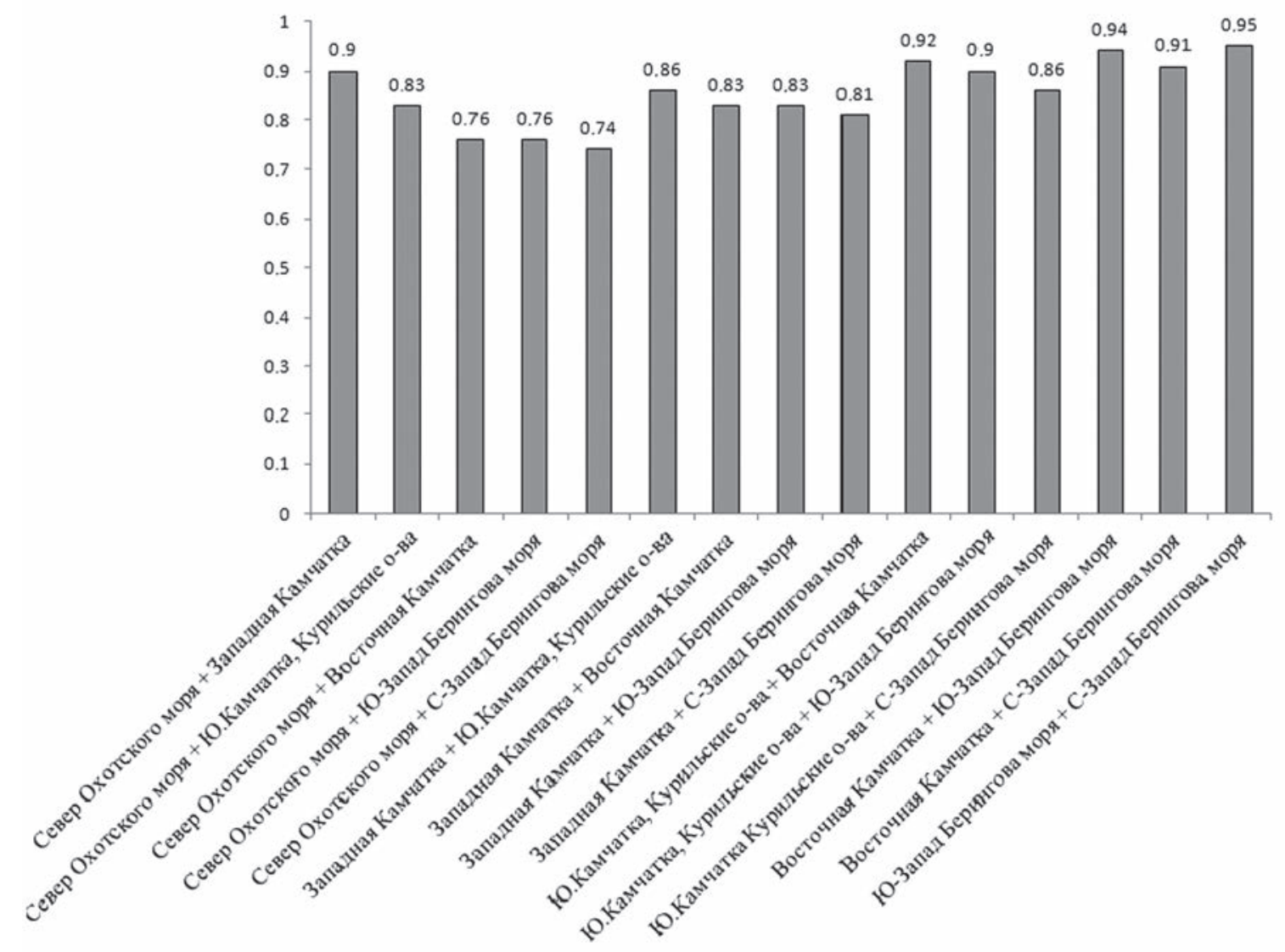

Puc. 5. Сходство видов морских рыб прикамчатских вод с известными ранними стадиями развития в районах их распространения. По горизонтали - сравниваемые районы, по вертикали - значения коэффициента фаунистической общности

Fig. 5. Similarity of the Kamchatka marine fishes species with known early stages of development in their distribution areas. Horizontally: areas compared. Vertically: values of the faunistic community coefficient

шие различия ихтиофауны выявлены между районами Охотского и Берингова моря, несмотря на близость широтного положения и сходство климатических условий в этих районах.

\section{ЗАКЛЮЧЕНИЕ}

Большинство видов морских рыб в прикамчатских, распространенных как в приазиатских, так и в приамериканских водах, доминируют по разнообразию зоогеографических группировок и занимают более широкий ареал распространения. Значительно меньше видов, встречающихся только в приазиатских водах. Наименьшую долю составляют виды атланто-тихоокеанского распространения. Климатические условия, несмотря на их общую суровость в районах исследований, имеют некоторые различия, что и может влиять на состав ихтиофауны.

Общность видов в условных смежных географических районах вдоль западного побережья Камчатки (районы - северная часть Охотского моря и Западная Камчатка) несколько меньше, чем в географических районах вдоль восточного побережья Камчатки, значительно разделенных по широте (например, районы Южная Камчатка с Курильскими островами и северо-западная часть Берингова моря). Скорее всего, на состав ихтиофауны оказывают влияние гидрологические условия (в частности, система течений). Так, гидрологический режим восточного побережья Камчатки во многом определяется ВосточноКамчатским течением, способствующим сглаживанию условий и широкому распространению видов, в том числе ихтиофауны. Условия морских вод вдоль западного побережья Камчатки отличаются. Гидрологических режим Охотского моря характеризуется наличием динамически активных зон, создающих круговороты водных масс и определяющих высокую продуктивность. Такие зоны, образующие круговороты водных масс на севере и юге западно-камчатского шельфа, могут влиять на состав ихтиофауны, особенно в ранний период развития, удерживая развивающиеся икринки и личинки.

Сходство видов морских рыб, обитающих в рассматриваемых условных географических районах, довольно высокое. Районы с наиболее близким видовым составом ихтиофауны: 
1 - север Охотского моря и Западная Камчатка; 2 - Восточная Камчатка и юго-западная часть Берингова моря; 3 - Южная Камчатка с северными Курильскими островами и Восточная Камчатка. Наибольшие различия ихтиофауны наблюдаются между районами Охотского и Берингова морей, что может быть связано с их большей географической изолированностью по сравнению с другими районами морских прикамчатских вод.

В зоогеографических группировках преобладают северно-бореальные и умереннобореальные виды, к которым относится большинство типично морских рыб из отрядов скорпенообразных, окунеобразных и камбалообразных. Большинство видов морских рыб с известными ранними стадиями развития, обитающих вблизи Камчатки, распространены как в приазиатских, так и в приамериканских водах (75.3\%). Виды северо-западно-тихоокеанского ареала распространения (не встречаются в приамериканских водах) составляют $17.1 \%$ от общего количества рассматриваемых видов. Небольшую долю (менее 7.6\%) составляют виды атланто-тихоокеанского ареала распространения. По зоогеографическим группировкам преобладают умеренно-бореальные $(43.8 \%)$ и севернобореальные (30.4\%) виды. Беднее по числу видов арктическо-бореальные (около 18\%) и арктические (2.9\%) рыбы. Как исключение, встречаются южно-бореальные (3.9\%) и субтропическобореальные (около 1\%) виды.

Небольшую разницу в количественном соотношении видов ихтиофауны в рассматриваемых районах можно объяснить географической близостью между собой этих районов, а также незначительными различиями в климатических условиях.

\section{ЛИТЕРАТУРА}

Андриямев А. П. Очерк зоогеографии и происхождения фауны рыб Берингова моря и сопредельных вод. Ленинград : Изд-во ЛГУ, 1939. 187 с.

Андриящев А. П. О некоторых вопросах вертикальной зональности морской донной фауны // Биологические ресурсы Мирового океана. Москва : Наука, 1979. C. $117-138$.

Беклемишев К. В., Парин Н. В., Семина Г. И. Пелагиаль // Океанология / Биологическая структура океана. Москва : Наука, 1977. Т. 1. С. 219-261.

Берг Л. С. Система рыбообразных и рыб, ныне живущих и ископаемых // Труды Зоологического ин-та АН СССР. Ленинград : Изд-во АН СССР, 1955. Т. 20. $286 \mathrm{c}$.

Бореи Л. А. Донные биоценозы Российского шельфа дальневосточных морей: состав, структура, элементы функционирования и промысловое значение. Владивосток : ТИНРО, 1997. $217 \mathrm{c.}$

Голиков А. Н., Кусакин О. Г. Фауна и экология брюхоногих переднежаберных моллюсков (Gastropoda, Prosobranchia) литорали Курильских островов // Ис- след. дальневост. морей СССР. 1962. Вып. 8. С. 248346.

Григорьев С. С. Ранние стадии рыб северо-востока России (прибрежные морские воды и внутренние водоемы): атлас-определитель. Владивосток : Дальнаука, $2007.331 \mathrm{c}$.

Григорьев С. С. Раннее развитие морских рыб северо-востока России. Морфобиологическая характеристика, особенности распределения. Saarbrucken, Germany: LAP Lambert Academic Publishing, 2013. 348 c.

Григорьев С. С., Седова Н. А. Распространение минтая Theragra chalcogramma (Pallas [1814]) в северной части Тихого океана - результат воздействия экологических факторов в ранний период развития // Сохранение биоразнообразия Камчатки и прилегающих морей : Материалы XVII междунар. науч. конф. 16-17 нояб. 2016 г. Петропавловск-Камчатский, 2016. C. $141-145$.

Дарлингтон Ф. Зоогеография. Географическое распространение животных. Москва : Прогресс, 1966. $519 \mathrm{c}$.

Датский А. В., Андронов П. Ю. Ихтиоцен верхнего шельфа северо-западной части Берингова моря. Магадан : СВНЦ ДВО РАН, 2007. 261 c.

Дьяков Ю.П. Камбалообразные (Pleuronectiformes) дальневосточных морей России (пространственная организация фауны, сезоны и продолжительность нереста, популяционная структура вида, динамика популяций) : автореф. дис. ... д-ра биол. наук. Владивосток, 2009. 48 c.

Елисеева И. И., Рукавишников В. О. Группировка, корреляция, распознавание образов: (статистические методы классификации и измерения связей). Москва : Статистика, 1977. $143 \mathrm{c}$.

Иванов О. А., Суханов В. В. Видовая структура нектона прикурильских и прикамчатских вод Тихого океана. Магадан : СВНЦ ДВО РАН, 2013. № 3. С. 48-71.

Каталог позвоночных Камчатки и сопредельных морских акваторий / под ред. Р. С. Моисеева и А. М. Токранова. Петропавловск-Камчатский : Камчатский печатный двор, 2000. 166 с.

Кафанов А. И. Двустворчатые моллюски и фаунистическая биогеография северной Пацифики. Владивосток : ДВО АН СССР, 1991. 196 c.

Кусакин О.Г. Морские и солоноватоводные равноногие ракообразные (Isopoda) холодных и умеренных вод Северного полушария // Определители по фауне СССР, издаваемые ЗИН АН СССР. Ленинград : Наука, 1979. T. $122.471 \mathrm{c}$.

Микулин A. E. Зоогеография рыб : учеб. пособие. Москва : Изд-во ВНИРО, 2003. $436 \mathrm{c.}$

Никольский Г. В. Экология рыб. Москва : Высш. шк., 1974. $367 \mathrm{c}$. $740 \mathrm{c}$.

Одум Ю. Основы экологии. Москва : Мир, 1975.

Парин Н. В. Ихтиофауна океанической эпипелагиали. Москва : Наука, 1968. 185 с.

Парин Н. В. Некоторые особенности пространственного распределения рыб океанической пелагиали // Биологические ресурсы Мирового океана. Москва : Наука, 1979. С. 102-112.

Петряшев В. В. Биогеографическое районирование сублиторали и верхней батиали северной ча- 
сти Тихого океана по фауне Mysidacea и Anomura (Crustacea) // Биология моря. 2005. Т. 31, № 4. C. 233-250.

Розенберг Г. С., Мозговой Д. П., Гелашвили Д. Б. Экология. Элементы теоретических конструкций современной экологии. Самара : СамНЦ РАН, 1999. 396 с.

Федоров В. В., Парин Н. В. Пелагические и бентопелагические рыбы тихоокеанских вод России. Москва : Изд-во ВНИРО, 1998. 156 с.

Федоров В. В., Черешнев И. А., Назаркин А. В., Шестаков A. В., Волобуев $B$. В. Каталог морских и пресноводных рыб северной части Охотского моря. Владивосток : Дальнаука, 2003. 198 с.

Черешнев И. А. Биогеография пресноводных рыб Дальнего Востока России. Владивосток : Дальнаука, $1998.130 \mathrm{c}$.

Черешнев И. А. Пресноводные рыбы Чукотки. Магадан : СВНЦ ДВО РАН, 2008. 324 с.

Черешнев И. А., Шестаков А. В., Скопеи М. Б. Определитель пресноводных рыб Северо-Востока России. Владивосток : Дальнаука, 2001. 128 с.

Шитиков В. К., Розенберг Г. С. Оценка биоразнообразия: попытка формального общения // Структурный анализ экологических систем / Количественные методы экологии и гидробиологии : сб. науч. тр., посвящ. памяти А. И. Баканова / отв. ред. чЛ.-корр. РАН
Г. С. Розенберг. Тольятти : СамНЦ РАН, 2005. С. 91129.

Шмидт П. Ю. Рыбы восточных морей Российской империи. Санкт-Петербург : Изд-во Геогр. о-ва, 1904. $466 \mathrm{c.}$

Шмидт П. Ю. Рыбы Охотского моря // Труды Тихоокеан. Комитета. 1950. Т. 6. С. 68-73.

AquaMaps Data sources: GBIF OBIS http://www.fishbase.se/summary/22679

An Atlas of the early stage fishes in Japan / ed. M. Okiyama. Tokyo : Tokai University Press, 1988. 1160 p.

Coulson M. W., Marshall H. D., Pepin P., Carr S. M. Mitochondrial genomics of gadine fishes: implications for taxonomy and biogeographic origins from wholegenome data sets // Genome. 2006. 49 (9): 1115-1130. doi:10.1139/g06-083

Eschmeyer W. F. Chalcogrammus, Gadus. Catalog of Fishes. California Academy of Sciences, 2012. http:// en.wikipedia.org/wiki/Gadus\#cite_note-18.

Matarese A. C., Kendall A. W., Blood D. M., Vinter $B$. M.. Laboratory guide to early life history stages of Northeast Pacific fishes. NOAA Technical Report NMFS 80. $1989.652 \mathrm{p}$.

The World Register of Marine Species (WoRMS) http://www.marinespecies.org/index.php

Поступила в редакиию 01.10.2018 2.

Поступила после доработки 16.09.2019 г.

\title{
ZOOGEOGRAPHICAL CHARACTERISTICS OF MARINE FISHES IN KAMCHATKA PENINSULA WATERS BASED ON THEIR EARLY STAGES OF DEVELOPMENT
}

\author{
S. S. Grigoriev', N. A. Sedova ${ }^{2}$ \\ ${ }^{1}$ Kamchatka Branch of the Pacific Institute of Geography FEB RAS, Petropavlovsk-Kamchatsky \\ ${ }^{2}$ Kamchatka State Technic University, Petropavlovsk-Kamchatsky \\ Compliance of reproductive areas of the fishes, inhabiting Kamchatka waters and in the western part \\ of the Bering Sea, to the modern views of their zoogeographical characteristics and origin of their \\ habitats is discussed. The spawning areas, differing in zoogeographical characteristics, are considered \\ in order to specify zoogeographical assessment of fish species. Most Kamchatka species of marine \\ fishes (75.3\%), with known early stages of development, are of the northern Pacific distribution. The \\ number of species of northwestern Pacific distribution is significantly smaller (17.1\%). The smallest \\ portion is fishes of the Atlantic-Pacific distribution (less than 7.6\%). In zoogeographic groups, \\ moderately-boreal and northern-boreal fishes dominate ( 43.8 and $30.4 \%$ of species, respectively). \\ Arctic-boreal and Arctic fishes are poor in the number of species (18 and 2.9\%, respectivel). As an \\ exception, there are southern-boreal (3.9\%) and boreal-subtropical (about 1\%) species.
}

Keywords: ichthyofauna, ichthyoplankton, zoogeographical characteristics, zoogeographical groups, faunistic community.

\section{REFERENCES}

An Atlas of the Early Stage Fishes in Japan, 1988. Ed. M. Okiyama. Tokyo, Tokai Uniersity Press.

Andriyashev, A. P., 1939. A Sketch of Zoogeography and the Origin of the Fauna of Fish of the Bering Sea and Adjacent Waters. Leningrad, Leningrad State University [In Russian].
Andriyashev, A. P., 1979. On Some Issues of the Vertical Zoning of Marine Benthic Fauna, Biological Resources of the Oceans. Moscow, Nauka. 117-138 [In Russian].

AquaMaps Data Sources: GBIF OBIS http://www. fishbase.se/summary/22679 
Beklemishev, R. V., Parin, N. V., Semina, G. I.,1977. Pelagial, Oceanology, Biological Structure of the Ocean. Moscow, Nauka, 1, 219-261 [In Russian].

Berg, L. S., 1955. The Systematics of Fishes and Pisciforms, Living and Fossil, Trudy Zoologicheskogo Instituta AN SSSR [In Russian].

Borets, L. A., 1997. Benthic Biocenoses of the Russian Shelf of the Far East Seas: Composition, Structure, Elements of Functioning, and Commercial Value. Vladivostok, TINRO [In Russian].

Catalog of Kamchatka's Vertebrates and Adjacent Marine Water Areas, Ed. by R. S. Moiseyev and A. M. Tokranov, 2000. Petropavlovsk-Kamchatsky, Kamchatka Printing Yard [In Russian].

Chereshnev, I. A., 1998. Biogeography of Freshwater Fishes in Russia's Far East. Vladivostok, Dal'nauka [In Russian].

Chereshnev, I. A., 2008. Freshwater Fishes of Chukotka, Magadan, Northeast Scientific Center, Far Eastern Branch of the Russian Academy of Sciences [In Russian]. Chereshnev, I. A., Shestakov, A. V., Skopets, M. B., 2001. Key to Freshwater Fishes in the North-East of Russia, Vladivostok, Dal'nauka [In Russian].

Coulson, M. W., Marshall, H. D., Pepin, P., Carr, S. M., 2006. Mitochondrial Genomics of Gadine Fishes: Implications for Taxonomy and Biogeographic Origins from Whole-Genome Data Sets, Genome. 49 (9), 1115 1130. DOI: $10.1139 / \mathrm{g} 06-083$

Darlington, F., 1966. Zoogeography, Geographical Distribution of Animals. Moscow, Progress [In Russian].

Datsky, A. V., Andronov, P. Yu., 2007. Ichthyocene of the Upper Shelf of the Northwestern Part of the Bering Sea. Magadan, Northeast Scientific Center, Far Eastern Branch of the Russian Academy of Sciences [In Russian].

Dyakov, Yu. P., 2009. Flatfishes (Pleuronectiformes) of the Far Eastern Seas of Russia (Spatial Organization of Fauna, Seasons, and Duration of Spawning, Population Structure of the Species, Population Dynamics) : Avtoref. Dis. ... Doctora Biol. Nauk. Vladivostok [In Russian].

Eschmeyer, W. F., 2012. Chalcogrammus, Gadus. Catalog of Fishes. California Academy of Sciences. http:// en.wikipedia.org/wiki/Gadus\#cite_note-18

Fyodorov, V. V., Chereshnev, I. A., Nazarkin, A. V., Shestakov, A. V., Volobuev, V. V., 2003. Catalog of Marine and Freshwater Fish in the Northern Part of the Sea of Okhotsk. Vladivostok, Dal'nauka [In Russian].

Fyodorov, V. V., Parin, N. V., 1998. Pelagic and Benthopelagic Fishes of Russia's Pacific Waters. Moscow, VNIRO [In Russian].

Golikov, A. N., Kusakin, O. G., 1962. The Fauna and Ecology of Gastropod Pronebranch Mollusks (Gastropoda, Prosobranchia) of the Kuril Islands Littoral, Researches of Far East. Seas of the USSR. 8, 248-346 [In Russian].

Grigoriev, S. S., 2007. Early Stages of Fishes of Russia's North-East (Coastal Marine and Fresh Waters) : An Atlas-Guide. Vladivostok, Dal'nauka [In Russian].

Grigoriev, S. S., 2013. Early Development of Marine

Fishes in Russia's North-East. Morphobiological Characteristics, Peculiarities of Distribution. Saarbrücken, Germany. LAP Lambert Academic Publishing [In Russian].

Grigoriev, S. S., Sedova, N. A., 2016. Distribution of Alaska Pollock Theragra chalcogramma (Pallas [1814]) in the North Pacific Ocean Resulted from the Environmental Factors Impact during the Early Ontogenesis, Conservation of Biodiversity of Kamchatka and the Adjacent Seas, Materials of XVII Scientific Conference. Petropavlovsk-Kamchatsky, 141-145 [In Russian].

Ivanov, O. A., Sukhanov, V. V., 2013. The Species Structure of the Nekton in the Kuril and Kamchatka Waters of the Pacific Ocean, Bulletin of the Northeast Scientific Center of the Far Eastern Branch of the Russian Academy of Sciences. Magadan, 48-71 [In Russian].

Kafanov, A. I., 1991. Bivalve Mollusks and Faunistic Biogeography of the North Pacific. Vladivostok, Far Eastern Branch of the Academy of Sciences of the USSR [In Russian].

Kusakin, O. G., 1979. Marine and Brackish-Water Isopod Crustaceans (Isopoda) of Cold and Temperate Waters of the Northern Hemisphere, Guidelines for the Fauna of the USSR, Published by the Zoological Institute, Academy of Sciences of the USSR. Leningrad, Nauka [In Russian].

Matarese, A. C., Kendall, A. W., Blood, D. M., Vinter B. M., 1989. Laboratory Guide to Early Life History Stages of Northeast Pacific Fishes. NOAA Technical Report NMFS 80.

Mikulin, A. E., 2003. Zoogeography of Fish: Study Guide. Moscow, VNIRO [In Russian].

Nikol'sky, G. V., 1974. Ecology of Fishes. Moscow, Vysshaya Shkola [In Russian].

Odum, Yu., 1975. Fundamentals of Ecology. Moscow, Mir [In Russian].

Parin, N. V., 1968. Ichthyofauna of the Oceanic Epipelagial. Moscow, Nauka [In Russian].

Parin, N. V., 1979. Some Features of Spatial Distribution of the Oceanic Pelagial Fish, Biological Resources of the Oceans. Moscow, Nauka, 102-112 [In Russian].

Petryashev, V.V., 2005. Biogeographic Zoning of the Sublittoral and Upper Bathyal of the Northern Part of the Pacific Ocean According to the Mysidacea and Anomura (Crustacea) Fauna, Marine Biology. 31 (4), 233-250 [In Russian].

Rosenberg, G. S., Mozgovoy, D. P., Gelashvili, D. B., 1999. Ecology. Elements of Theoretical Constructions of Modern Ecology. Samara, Samara Scientific Center, Russian Academy of Sciences [In Russian].

Schmidt, P. Yu., 1904. Fishes of the Eastern Seas of the Russian Empire, St. Petersburg, Geographic Society [In Russian].

Schmidt, P. Yu., 1950. Fishes of the Sea of Okhotsk, Proceedings of the Pacific Committee. 6, 68-73 [In Russian].

Shitikov, V. K., Rosenberg, G. S., 2005. Assessment of Biodiversity: Attempt of Formal Communication, Structural Analysis of Ecological Systems. Quantitative Methods of Ecology and Hydrobiology: Collection of Scientific Papers Dedicated to the Memory of A. I. Bakanov, Ed. G. S. Rosenberg. Togliatti, Samara Scientific Center, Russian Academy of Sciences, 91-129 [In Russian].

The World Register of Marine Species (WoRMS) http://www.marinespecies.org/index.php

Yeliseyeva, I. I., Rukavishnikov, V. O., 1977. Grouping, Correlation, Pattern Recognition: (Statistical Methods for Classifying and Measuring Relationships). Moscow, Statistica [In Russian]. 